Acta Universitatis Nicolai Copernici • Pedagogika XXXI/2015

Nauki Humanistyczno-Społeczne • Zeszyt 426

DOI: http://dx.doi.org/10.12775/AUNC_PED.2015.011

\author{
Ewelina Wesołek \\ Wydział Nauk Pedagogicznych \\ Uniwersytet Mikołaja Kopernika w Toruniu
}

\title{
Maciej Krzemiński, Dziecko i młodzież. Przestrzenie literackie, kulturowe $i$ wychowawcze, Wydawnictwo Edukacyjne AKAPIT, Toruń 2015, ss. 160
}

\begin{abstract}
Drzedmiotem mojej recenzji jest książka autorstwa Macieja Krze- mińskiego Dziecko i młodzież. Przestrzenie literackie, kulturowe $i$ wychowawcze, wydana przez Wydawnictwo Edukacyjne AKAPIT w 2015 roku w Toruniu. Maciej Krzemiński jest doktorem nauk humanistycznych, ekspertem w zakresie współczesnej literatury polskiej i powszechnej.
\end{abstract}

Praca skład się z sześciu rozdziałów, wstępu i bibliografii. W swojej pracy autor skupił się na dzieciństwie i młodości jako okresach w życiu człowieka, dla których wychowanie i edukacja są elementami kluczowymi. Autor zaznacza, że podejmowane problemy nie są tylko domeną pedagogów, ponieważ „od wieków zmagają się z nimi także pisarze i poeci"1.

Rozdział pierwszy dotyczy wykorzystania baśni magicznej w procesie dydaktycznym i wychowawczym. Na początku zostały przedstawione wybrane fakty dotyczące historii baśni folklorystycznych, a następnie autor przeanalizował rolę, jaką spełnia baśń ludowa w życiu

${ }^{1}$ M. Krzemiński, Dziecko i młodziė. Przestrzenie literackie, kulturowe i wychowawcze, Toruń 2015, s. 7. 
młodego czytelnika - w tym celu odwołał się do badań Stefana Szumana dotyczących wpływu lektury baśni ludowej na psychikę i wychowanie dziecka. Następnie Krzemiński przedstawił wychowawczą i edukacyjną wartość baśni w świetle opinii Brunona Bettelheima. Krzemiński podkreślił edukacyjno-wychowawczy potencjał bajki magicznej w tworzeniu dziecięcej aksjologii.

W rozdziale drugim zatytułowanym Czy szkoła może być szkoła życia? Krzemiński skoncentrował się na przedstawieniu problematyki związanej ze szkołą, szczególnie ze sposobem, w jaki wpływa ona na życie ludzi, akcentując pozadydaktyczny wymiar jej funkcjonowania. Pierwszą powieść, jaką przywołuje, jest Pierwsza Miłość Sándora Máraia, którą określa jako „studium przypadku odkrywające tajemnicę ludzkiej natury"”. Autor zwraca uwagę na opresyjne środowisko szkolne oraz uwarunkowania historyczno-obyczajowe przedstawione w powieści Máraia. Krzemiński ukazuje również kontekst psychologiczny dotyczący głównego bohatera, a skupiając się na jego trudnym dzieciństwie, stara się je wyjaśnić, przywołując koncepcje Zygmunta Freuda. Druga omawiana przez Krzemińskiego powieść to Przechowalnia Kazimierza Orłosia. Na początku autor krótko charakteryzuje młodzież czasów PRL-u oraz dokonuje specyfiki peerelowskiej oświaty. Następnie przywołuje realia życia w szkole na podstawie powieści Orłosia. Zwraca uwagę, że „Literatura realistyczna, mocno osadzona w prozaicznej materii życia [...] posiada ważny atut, jakim jest jej wartość dokumentalna"3.

W trzecim rozdziale zatytułowanym Droga $w$ przestrzeni $i$ droga $w$ głą siebie - dwa warianty Krzemiński podejmuje zagadnienia relacji międzyludzkich opartych na silnym zaangażowaniu uczuciowym; ujmuje to w motyw wędrówki. Relacje rodzinne przedstawione zostały jako zagrożone rozwojem cywilizacyjnym. W pierwszej części rozdziału przedstawia dwie powieści: Śmierć Bunny'ego Munro Nicka Cave’a oraz powieść Cormaca McCarthy'ego zatytułowaną Droga. Autor podkreśla, że bohaterowie przywołanych powieści stanowią przykład opisu istotnych momentów procesu wychowania dokonującego się w re-

\footnotetext{
2 Tamże, s. 42.

3 Tamże, s. 51.
} 
lacjach ojca z synem oraz „prowokują do refleksji nad zagrożeniami wynikającymi z postępu cywilizacji”" i miejsca, jakie będą zajmować w tym świecie dzieci. Krzemiński w analizie obu tekstów odwołuje się do licznych prac naukowych, starając się na ich podstawie wyjaśnić zachowanie bohaterów. Trzecią powieścią przytaczaną w tym rozdziale jest Poczucie kresu Juliana Barnesa. Przed omówieniem problematyki powieści autor przedstawia kilka teorii naukowych dotyczących sposobu działania pamięci. Krzemiński skupia się na pytaniu, czy możliwe jest poznanie samego siebie oraz w jaki sposób widzimy siebie, tworząc mylne wyobrażenia spowodowane upływem czasu.

Rozdział czwarty zatytułowany Dziecięce poznawanie zła - zagrożenie, ekspiacja czy wyzwolenie? poświęcony został dziecięcym bohaterom poznającym oblicza zła. W tej części Krzemiński dokonuje analizy powieści Georgesa-Artura Goldschmidta oraz opowiadania Kazimierza Orłosia. W powieści Odosobnienie Georgesa-Artura Goldschmidta, zwraca uwagę na problematykę dojrzewania do ciała, poczucia winy i wstydu oraz tęsknoty i samotności. W opowiadaniu Kazimierza Orłosia Dziewczyna z łódki zwrócono uwagę na symbolikę dotyczącą natury, inicjacji i zła. Krzemiński zaznacza, że inicjacja stanowi wejście w tajemnicę życia. Ważnym elementem opowiadania jest motyw dorastania człowieka do odpowiedzialności za własne postępowanie, ale i uniwersalna przestroga przed złem czającym się w pozornie błahych zdarzeniach.

Rozdział piąty Młodzi wystawiaja rachunki swoim rodzicom skupia się wokół trzech książek. Jako pierwszy Krzemiński omawia zbiór reportaży pod tytułem Niemiecka jesień autorstwa Stiga Dagermana. Książka jest zbiorem reportaży opisujących powojenną rzeczywistość Niemiec. Analizując ją, autor skupia się na problemie winy i kary oraz odpowiedzialności za popełnione zbrodnie podczas wojny. W cytowanych fragmentach książki Dagermana pokazuje losy niemieckiej młodzieży oraz dzieci jako ofiar wielkich ideologii. Zastanawia się również nad kwestią wybaczenia krzywd wyrządzonych przez Niemców w czasie ostatniej wojny światowej. Drugą książką wybraną przez Krzemińskiego jest Noc żywych Żydów Igora Ostachowicza. Po-

\footnotetext{
4 Tamże, s. 68.
} 
wieść ukazuje współczesną Warszawę, w której pojawiają się zmarłe w czasie wojny dzieci żydowskie. Krzemiński, przytaczając tę powieść, zwraca uwagę na współczesne znaczenie historii, sposób, w jaki wpływa ona na teraźniejszość. Trzecią powieścią jest Będzie gorzej autorstwa Jana Pelca. Książka traktuje o pokoleniu młodych ludzi, członków ruchu hipisowskiego w Czechosłowacji. Omawiając tę powieść, autor skupia się na skrajnie pojmowanej niezależność bohatera powieści Pelca, która prowadzi do zagrożenia jego życia. Ideały wolności pokoju i miłości pojmowane przez młodych członków subkultury hipisów w sposób bardzo ortodoksyjny ujawniają swoją utopijność oraz obnażają ludzkie ograniczenia.

W ostatnim szósty rozdział zatytułowany Muzyka młodzieżowa poszukiwaniem własnej tożsamości Krzemiński analizuje książkę Mikaela Niemiego Muzyka pop z Vittuli oraz twórczość zespołu Republika. Muzyka pop z Vittuli to powieść, w której dorosły już bohater z perspektyw swojego dzieciństwa opowiada o zmianach, jakie zachodzą na prowincjonalnym pograniczu fińsko-szwedzkim w okresie transformacji ekonomicznej i kulturowej. To właśnie zmiany będące wynikiem globalnych procesów oraz atmosfera panująca na pograniczu fińsko-szwedzkim są jednym z omawianych wątków powieści. Kolejnymi ważnymi kwestiami, na jakie zwraca uwagę autor, jest problem przemocy wobec uczniów i nauczycieli obecny w szkole oraz poza nią i wynikający z modelu wychowania oraz aprobowanych przez dorosłych zachowań. Przywołane wcześniej zmiany społeczno-obyczajowe prowadzą do zmiany tradycyjnych ról i wzorców postępowania mężczyzn i kobiet, a wpływ kultury masowej wpływa na życie mieszkańców, na co wskazuje autor. Następnie omówione zostały teksty autorstwa Grzegorza Ciechowskiego, lidera zespołu Republika. Na samym początku autor wyjaśnia sytuację społeczno-polityczną lat 80. w kontekście polskiej sceny muzycznej. Następnie analizuje teksty piosenek, określając je jako „fascynację zmysłową. Gwałtowną i śmiertelnie groźną erotykę istniejącą w budzącym lęk porządku społecznym"5. Krzemiński pokazuje problem młodzieży budującej własną tożsamość w kontekście zjawisk muzycznych i popkulturowych.

\footnotetext{
5 Tamże, s. 153.
} 
Recenzowana książka stanowi interdyscyplinarne ujęcie problematyki okresu dzieciństwa i młodości w obszarach literackich, kulturowych i wychowawczych. Autor dokonuje analizy i syntezy tekstów literackich z obszarów popkultury i zjawisk tworzących współczesną cywilizację. Obok interpretacji utworów literackich polskich i zagranicznych wyjaśnia zachowania bohaterów oraz opisywane sytuacje, odwołując się do eksplikacji naukowych. Podczas interpretacji tekstów korzysta między innymi z prac naukowych pedagogów, psychologów, socjologów, historyków oraz politologów, co pozwala na umieszczenie omawianego tekstu w obszarze nauk humanistyczno-społecznych. 
